\title{
The workability kinetics of phosphogypsum binder
}

\author{
Girts Bumanis ${ }^{1}$, Jelizaveta Zorica ${ }^{2}$, Ina Pundiené ${ }^{3}$, Diana Bajare ${ }^{4}$ \\ ${ }^{1,2,4}$ Department of Building Materials and Products, Riga Technical University, Riga, Latvia \\ ${ }^{3}$ Laboratory of Concrete Technologies, Vilnius Gediminas Technical University, Vilnius, Lithuania
}

\section{E-mail: 'Igirts.bumanis@rtu.lv (corresponding author)}

\begin{abstract}
The dihydrate phosphogypsum (PG) based binder workability kinetics were investigated regarding to waterbinder ratio (W/B) and chemical admixtures added to the composition of PG paste. PG was dried at $60{ }^{\circ} \mathrm{C}$ and homogenized to powder like particles with collision milling in disintegrator and calcium sulphate hemihydrate was obtained by heating PG at $180^{\circ} \mathrm{C}$. The obtained binder chemical, mineralogical and technological properties were tested and compared to commercial gypsum plaster. Early age $(2 \mathrm{~h})$ and $14 \mathrm{~d}$ compression strength was determined. The workability and setting time of both - PG and commercial gypsum was investigated with viscosimeter, ultrasonic pulse velocity and Vicat apparatus and correlation between testing methods was obtained. Results indicate that binder based on PG has slightly lower $\mathrm{pH}(\mathrm{pH}$ 6.3) than commercial binder $(\mathrm{pH} 6.8)$ and finer particle size grading leading to increased W/B ratio and more rapid initial setting time. The set retarder could efficiently increase the setting time of PG binder giving extra workability time which is positive factor for prolonged treatment of binder slurry, i.e. to prepare porous gypsum binder. Such approach would give a safer alternative to PG disposal, closing the materials loop and enhancing the circularity of this material.
\end{abstract}

Keywords: phosphogypsum, workability, technological properties, setting time.

\section{Introduction}

The potential of PG as secondary raw material in construction industry is with high potential if compared to other building materials from the point of view of total energy consumption and $\mathrm{CO}_{2}$ emissions (Kaminskas, 2002). However the PG could be contaminated with technological impurities such as orthophosphoric acid, sulfuric acid, calcium orthophosphate, calcium fluoride, hexafluorosilicic acid, phosphates and other rare element earth metals (Gaidučis, 2009). There are production plants where the impurities are eliminated by washing PG with water or separating off coarse and very fine particles as the most impurities in PG can be found in the particle size fractions above 160 and below $25 \mu \mathrm{m}$; while up to $4 \mathrm{~m}^{3}$ of water is necessary to wash 1 ton of PG (Kaziliunas, Leskeviciene, Vektaris, \& Valancius, 2006). The PG contamination are also eliminated by using a combined method when PG is washed with a smaller amount of water, and the rest of the acid admixtures are neutralized by adding the alkaline nature additives. The soluble impurities are converted to insoluble matters such as calcium orthophosphates of the hydroxyl apatite group and fluorides, having little influence on the properties of binder (Singh, 2003).

Although the significance and use of secondary gypsum based materials is growing, the influence of water-gypsum ratio and chemical admixtures on the fresh paste behaviour and properties of gypsum-based materials has not been studied adequately. It has been reported by Moraes Rossetto et al., that binder obtained from recycled gypsum plaster has much poorer workability comparing to commercial gypsum and it was suggested that chemical admixtures should be used (de Moraes Rossetto, Correia, Geraldo, \& Camarini, 2015; Bumanis, Zorica, Bajare, \& Korjakins, 2018). Previously it has been reported that by including PG in the matrix, the workability, unit weight and mechanical strength reduces due to low density of the material (Rashad, 2017). One of the ways to improve workability of gypsum paste is to increase water-binder (W/B) ratio. However as it is reported before the strength of the material is reduced significantly as the porosity of the material increased (Bumanis et al., 2018). Another, more effective way to improve workability and reduce W/B is to use superplasticizers. Traditionally superplasticizers are used from $0.2-1 \%$ from the weight of gypsum and the most common plasticizers used are naphthalene, melamine, polycarboxylate and citric acid which may act both as gypsum setting time retarders or accelerators (Camarini, Pinto, Moura, \& Manzo, 2016; Dolák \& Dvořák, 2016; Sakthieswaran \& Sophia, 2018). The water reduction by superplasticizers depending from the amount added could reach from 2.5-25 wt.\% (Sakthieswaran \& Sophia, 2018). For gypsum binder compressive strength could be in range from 8-20 MPa, depending from W/B which might be decreased by using superplasticizers (Sakthieswaran

(C) 2019 Authors. Published by VGTU Press. This is an open-access article distributed under the terms of the Creative Commons Attribution (http://creativecommons.org/licenses/by/4.0/) License, which permits unrestricted use, distribution, and reproduction in any medium, provided the original author and source are credited. 
\& Sophia, 2018). Some reports say that there is a reduction on the efficiency of the polycarboxylates that is linked to the presence of impurities in the raw material. Researchers in the gypsum and chemical industry agree that there is an interaction between the polycarboxylate superplasticizers and the gypsum containing impurities (Contreras, 2014). The impurities make the natural gypsum incompatible with the polycarboxylate superplasticizer. This would interfere with the expected results and lead to poor dosage response and an increasing water demand giving low efficiency of polycarboxylate superplasticizer usage.

Another problem is associated with rapid setting time of PG binder therefore set retarders should be considered to improve technological properties of binder (Bumanis et al., 2018). The most common retarders which are used with gypsum binder are sodium gluconate and citric acid, which may also improves paste workability ( $\mathrm{Li}, \mathrm{He}, \mathrm{Hu}, \mathrm{Huang}$, \& Shi, 2012). Some reports say that by using citric acid compressive strength might be reduced (Lanzón \& GarcíaRuiz, 2012; Camarini et al., 2016).

Most often ultrasonic measurements are made to characterize hardened gypsum and is used as an indicator of crystallization, i.e. Lanzon and Garcia-Ruiz has reported that when citric acid is used the gypsum samples the ultrasonic measurements indicates that gypsum samples are less rigid due to the lower degree of interlocking of the gypsum crystals (Lanzón \& García-Ruiz, 2012). In present research ultrasonic pulse velocity and dynamic viscosity were used to describe gypsum paste properties and start of setting time and compared to traditional methods. PG was considered as raw material for gypsum binder and chemical and technological properties were compared with commercial gypsum binder.

\section{Materials and methods}

Air dry dihydrate phosphogypsum (PG) obtained from open stacks of fertilizer production plant (AB Lifosa, Lithuania) were used. During the production PG was extracted from Kovdor apatite (Russia) and phosphorite from South Africa in ratio of $4: 1$ and it was used in the investigation. The temperature of extracted PG directly after production is $62-69{ }^{\circ} \mathrm{C}$ and the typical moisture content is from $23-29 \%$. Extracted PG is stored in open stacks where hydration and dissolution processes occur. The initial $\mathrm{pH}$ of $\mathrm{PG}$ is in range from 2.2-2.9 while during the storage it can increase gradually. The PG was dried at $60{ }^{\circ} \mathrm{C}$ (moisture content 9-12 wt.\%) and milled to powder like particles with collision milling in semi-industrial disintegrator with the rotational speed of $50 \mathrm{~Hz}$. Then the calcium sulphate hemihydrate binder was obtained by heating milled gypsum powder at $180^{\circ} \mathrm{C}$ for $4 \mathrm{~h}$. Knauf commercial gypsum plaster (BG) was used to compare chemical composition and technological properties.

The chemical composition of the gypsum was determined using a Thermo Scientific ARL PERFORM'X Wavelength Dispersive X-Ray Fluorescence Spectrometer (WDXRF) with a Rh-target X-ray tube and the UniQuant program. Prior to the measurements, samples were dried at $60{ }^{\circ} \mathrm{C}$ and heated at $950{ }^{\circ} \mathrm{C}$; a fused bead was then prepared with lithium tetraborate $50 \%$ /lithium metaborate $50 \%$, with a $1: 10$ mixture of the $\mathrm{PG}$ and flux heated at $1085^{\circ} \mathrm{C}$. The chemical composition of $\mathrm{PG}$ is given in Table 1.

Table 1. Chemical composition of phosphogypsum (PG), PG binder and commercial gypsum (BG)

\begin{tabular}{|c|c|c|c|}
\hline & BG & PG & PG $180{ }^{\circ} \mathrm{C}$ \\
\hline $\mathrm{LOI} 950{ }^{\circ} \mathrm{C}$ & 22.43 & 19.24 & 6.89 \\
\hline $\mathrm{Na}_{2} \mathrm{O}$ & 0.31 & 0.48 & 0.47 \\
\hline $\mathrm{MgO}$ & 3.92 & 0.21 & 0.16 \\
\hline $\mathrm{Al}_{2} \mathrm{O}_{3}$ & 1.68 & 0.71 & 0.96 \\
\hline $\mathrm{SiO}_{2}$ & 3.73 & 1.07 & 0.94 \\
\hline $\mathrm{P}_{2} \mathrm{O}_{5}$ & 0.00 & 0.57 & 0.66 \\
\hline $\mathrm{SO}_{3}$ & 30.90 & 37.38 & 43.21 \\
\hline $\mathrm{CaO}$ & 35.64 & 37.16 & 0.08 \\
\hline $\mathrm{TiO}_{2}$ & 0.05 & 0.11 & 0.21 \\
\hline $\mathrm{Fe}_{2} \mathrm{O}_{3}$ & 0.22 & 0.13 \\
\hline $\mathrm{As}_{2} \mathrm{O}_{3}$ & 0.46 & 0.09 & 2.52 \\
\hline $\mathrm{SrO}$ & 0.07 & 2.25 & 0.24 \\
\hline $\mathrm{CeO}_{2}$ & 0.23 & 0.24 & 99.73 \\
\hline
\end{tabular}

The total amount of calcium sulphate dihydrate is $91.6 \%$. According to the content of calcium sulphate (up to $87 \%$ ) the PG corresponds close to the top grade natural gypsum (91-95\%) and is similar to that with BG, where calcium 
sulphate content is also around $86 \%$. Therefore, PG can be used as the raw material for the production of gypsumbased binders; however, the impurities remaining after the washing of orthophosphoric acid prevent the industrial use of this material. Small amount of $\mathrm{SiO}_{2}(1.07 \%)$ is present in the composition of PG. The characteristic constituent of $\mathrm{PG}$ is $\mathrm{P}_{2} \mathrm{O}_{5}$, which is absent in $\mathrm{BG}$. The total phosphorus pentoxide $\mathrm{P}_{2} \mathrm{O}_{5}{ }^{(\mathrm{T})}$ content was $0.57 \% . \mathrm{P}_{2} \mathrm{O}_{5}$ may attract water and in reaction with it forms phosphoric acid which is one of the decreasing workability of PG factors (Bumanis et al., 2018). The weight loss for hydrated gypsum (BG and PG) was 22.43 and $19.24 \%$ for BG and PG respectively, indicating hydration process of the gypsum binder is in compliance with the literature (Nizevičienè, Vaičiukynienè, Vaitkevičius, \& Rudžionis, 2016). PG binder weight loss was $6.89 \%$ at $950{ }^{\circ} \mathrm{C}$, which indicates that PG hemihydrate was obtained by heat treatment of dihydrate at $180{ }^{\circ} \mathrm{C}$ and corresponds to the literature where $6.4 \%$ loss is given (Nizevičienè et al., 2018).

The PG is contaminated in small amount with technological impurities such as $\mathrm{SrO}, \mathrm{CeO}_{2}, \mathrm{As}_{2} \mathrm{O}_{3}$ and other rare element earth metals which results from source phosphate rock ore as remains after its processing. Also SrO is detected in natural gypsum where it is described as marker for distinguishing of gypsum origin, the PG has 10 fold higher value of $\mathrm{SrO}$ in the chemical composition (Golež, Pogačnik, \& Mladenović, 2018).

The particle size distribution of prepared gypsum binders is given in Figure $1.100 \%$ of particles are below $0.3 \mathrm{~mm}$ which is in accordance with standard LVS EN 13279-1:2008. PG has finer nature comparing to BG. The characteristic value of $\mathrm{d}_{10}$ was $0.05 \mathrm{~mm}, \mathrm{~d}_{50}-0.075 \mathrm{~mm}, \mathrm{~d}_{90}-0.12 \mathrm{~mm}$ for PG and $0.08,0.13$ and $0.22 \mathrm{~mm}$ for BG respectively. The high fineness of gypsum could lead to increased W/B ratio and reduced setting time similar as for Portland cement reported previously (Naceri \& Benia, 2006).

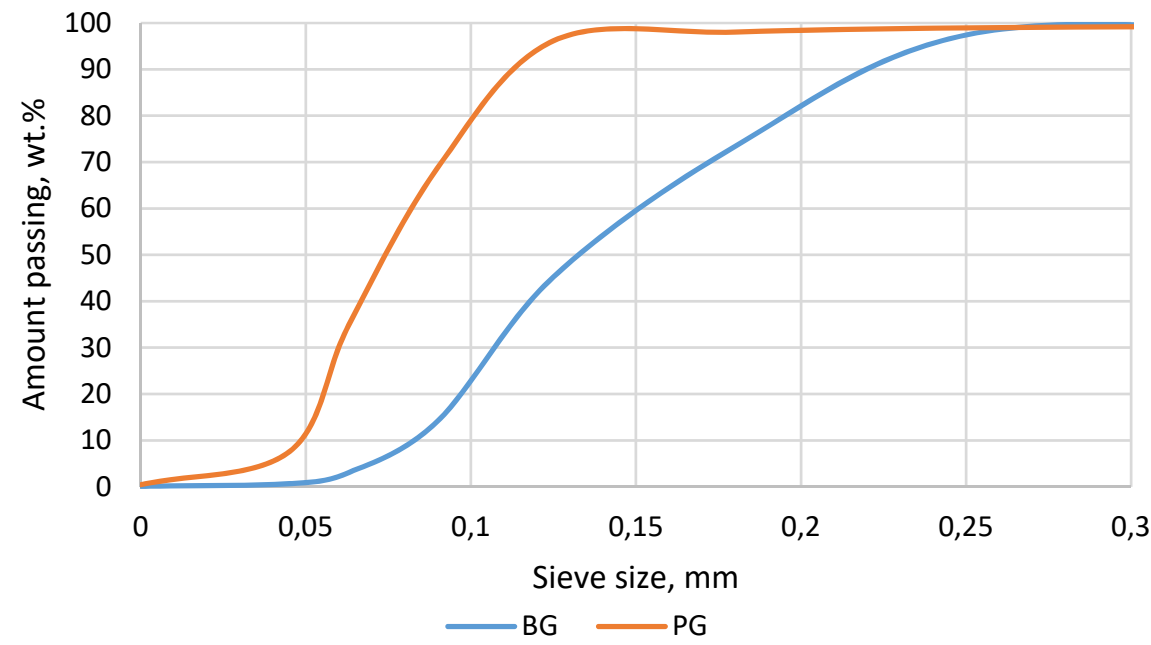

Figure 1. Particle size distribution of commercial gypsum (BG) and phosphogypsum after collision milling in disintegrator and heating at $180^{\circ} \mathrm{C}(\mathrm{PG})$

The mixture composition of tested gypsum binder is given in Table 2. To obtain workable paste W/B ratio was 0.45 for commercial gypsum BG while due to finer nature of PG the W/B ratio increased dramatically and PG paste with W/B ratio $0.7,0.8$ and 0.9 was examined. The paste workability was measured by Suttard viscosimeter which is widely used for testing of gypsum paste consistency.

Table 2. Mixture compositions of gypsum binding materials

\begin{tabular}{|l|c|c|c|c|c|c|}
\hline \multicolumn{1}{|c|}{ Component } & BG0.45 & PG0.7 & PG0.8 & PG0.9 & PGR & PGL \\
\hline Commercial gypsum & 1 & - & - & - & - & - \\
Heat treated PG* & - & 1 & 1 & 1 & 1 & 1 \\
Water & 0.45 & 0.7 & 0.8 & 0.9 & 0.8 & 0.8 \\
Retarder & - & - & - & - & $0.5 \%$ & - \\
Plasticizer & - & - & - & - & - & $1 \%$ \\
\hline
\end{tabular}

*prepared mixture composition with dihydrate phosphogypsum treated at $180{ }^{\circ} \mathrm{C}$ temperature.

To improve workability and increase setting time of PG binder, the composition with setting time retarder and lignosulphonate based plasticizer was evaluated. The setting time retarder Gips RETARD (TKK, Slovenia) was used as setting time retarder. The retarder content was $0.5 \%$ from mass of gypsum (composition PGR) and lignosulphonate based plasticizer (Mapeplast P, Mapei) content was 1\% (composition PGL) from the amount of water for composition with W/B 0.8 . 
The workability kinetics of prepared gypsum pastes were determined with the vibro-viscometer SV-10 (capacity - up to $12.000 \mathrm{mPa} \cdot \mathrm{s}$, accuracy $-0.01 \mathrm{mPa} \cdot \mathrm{s}$ ) until resistance of the paste reached $5000 \mathrm{mPa} \cdot \mathrm{s}$. Schleibinger Geräte $\mathrm{GmbH}$ datalogger with the Pundit 7 ultrasonic pulse indicator was used for investigation of ultrasonic wave velocity (UWV) in pastes and castable samples. Fresh pastes were set into special ring between two ultrasonic transducers operating at 10 pulses per second and frequency of $54 \mathrm{kHz}$. For castable samples UWV measurements were carried out without special ring equipment.

The selected mixture compositions were mixed with hand mixer for $30 \mathrm{sec}$ with water and measurements started 1 min after mixing for viscosity and 2 min for testing of UWV. The $\mathrm{pH}$ of fresh paste was determined with the MPC 227 instrument manufactured by Mettler-Toledo $\mathrm{pH}$ electrode InLab 410.

The setting time of obtained binder was tested using Vicat apparatus. Early age ( $2 \mathrm{~h})$ and long term (14 d) compressive strength of samples with dimension of $20 \times 20 \times 20 \mathrm{~mm}$ was tested using Zwick Z100 with testing speed $0.5 \mathrm{~mm} / \mathrm{min}$. Moisture content of prepared samples was determined by drying samples at $40{ }^{\circ} \mathrm{C}$ temperature until constant mass was reached. The specific gravity and total porosity was determined by using Le Chatelier flask. The mineralogical composition was determined by X-ray diffraction (XRD) (PAN analytical X'Pert PRO).

\section{Results}

The mineralogical composition of PG transformation through dehydration and hydration processes is given in Figure 2. The main mineral in dihydrate $\mathrm{PG}$ was synthetic calcium sulfate hydrate $\left(\mathrm{CaSO}_{4} 2 \mathrm{H}_{2} \mathrm{O}\right.$, ref. 33-0311). The dehydration at $180{ }^{\circ} \mathrm{C}$ for $4 \mathrm{~h}$ results in weight loss of $18 \mathrm{wt} . \%$ of chemically bonded water and new phase - calcium sulfate hemihydrate $\left(2 \mathrm{CaSO}_{4} \cdot \mathrm{H}_{2} \mathrm{O}\right.$, ref. $\left.02-0667\right)$ was detected. For hardened samples prepared from $\mathrm{PG}$ treated at $180{ }^{\circ} \mathrm{C}(\mathrm{PG} 0.8)$ main mineral detected was calcium sulfate hydrate (ref 72-0596) indicating reverse reaction to dehydration.

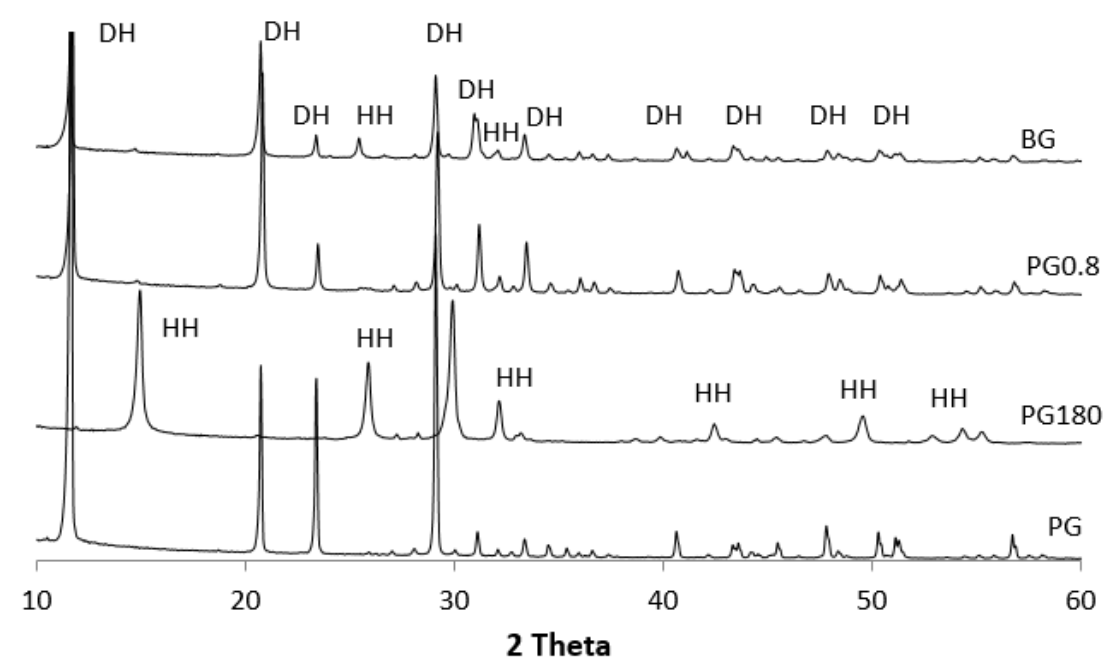

Figure 2. Mineralogical composition of phosphogypsum. DH - calcium sulfate hydrate (33-0311), $\mathrm{HH}$ - calcium sulfate hydrate (02-0667)

Prismatic grain microstructure can be observed both for BG and PG0.8 (Figure 3). The prismatic grains were shorter and narrower for BG, at the same time share of submicroscopic xenomorphic particles were relatively greater for PG. Previously it has been reported that the presence of submicroscopic particles, similar as $\beta$-gypsum or anhydrite III, can negatively influence technological properties, i.e. submicroscopic samples, immediately after mixing with water passing into dihydrate, acted as crystal germ and so as very effective accelerator of hardening (Dvořák, Gazdič, Petranek, Hájková, \& Magrla, 2014). The small white particles detected in sample made with PG are associated with strontium as confirmed by other authors (Golež et al., 2018).

Dry density of samples depended directly on W/B ratio and was almost not affected by admixtures, as it can be seen in Table 3. Density of samples with W/B ratio 0.8 was $1035-1060 \mathrm{~kg} / \mathrm{m}^{3}$, porosity $53.0-54.3 \mathrm{vol} \%$, and with increase of W/B total porosity also raised resulting with smaller density $-960 \mathrm{~kg} / \mathrm{m}^{3}$ and $57.4 \mathrm{vol} \%$ for PG0.9 respectively. Same effect observed in reversed case, by decreasing W/B ratio to 0.7 and 0.45 it consequence as 1130 and $1290 \mathrm{~kg} / \mathrm{m}^{3}$ for PG and BG. Factors as setting time, W/B ratio, admixtures and free moisture in the samples affected early compressive strength $(2 \mathrm{~h})$. After the compressive test specimens was dried at $60{ }^{\circ} \mathrm{C}$ to determine moisture content and it was from 20.5 to $33.3 \mathrm{wt} \%$ and correlates with W/B ratio. All aspects listed resulted as BG0.45 and PG0.7 to have highest early compressive strength 6.9 and 5.2 MPa. Early compressive strength for PG0.8 was 4.2 MPa and it was decreased both by W/B ratio increase and admixtures added. Tendencies of early compressive strength between mixtures persist in the 7th day compressive strength. Retarder dramatically affected strength of specimens, resulting 


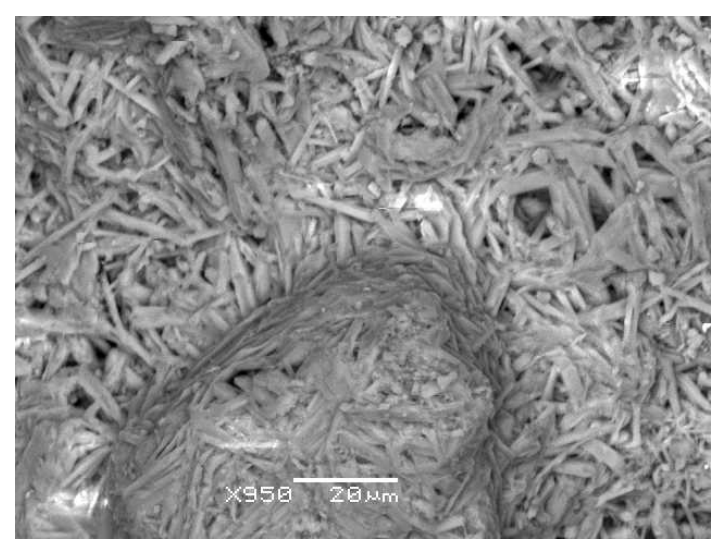

a)

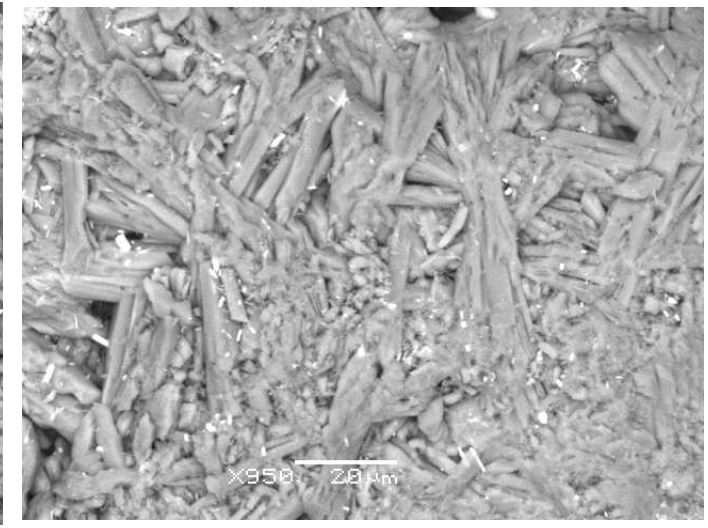

b)

Figure 3. Morphology of commercial gypsum (a) and phosphogypsum (PG0.8) after hydration. 950× magnification

as 1.3 and 3.4 MPa, tested after $2 \mathrm{~h}$ and $7 \mathrm{~d}$. The retarder used in this research are based on citric acid which is known to have tendency to reduce gypsum strength (Lanzón \& García-Ruiz, 2012; Camarini et al., 2016). Plasticizer had similar effect on binder a decrease of compressive strength was observed. Although admixtures presented negative effect on specimens' strength, they extended setting time of mixtures, which is positive workability factor. For PG without admixtures initial setting time was 04:20-04:45 min and final setting time 06:30-07:45 min, which increased to 1:40:00 till 2:10:00 for PG with retarded and from 09:30 till 18:40 min with plasticizer. In comparison it is clearly seen, that PG can reach BG workability level only with the help of the chemical admixtures, but still there is room for research on how to prolong setting time without the decrease of compressive strength. The increased W/B ratio and reduced setting time could be associated with high fineness of gypsum, which is similar as for Portland cement (Naceri \& Benia, 2006).

The $\mathrm{pH}$ of fresh paste was $\mathrm{pH} 6.8$ for $\mathrm{BG}$ and slightly lower for pastes made of $\mathrm{PG}-\mathrm{pH} 6.3$ and up to $\mathrm{pH}$ up to 6.5 with chemical admixtures.

Table 3. Physical properties of binders made of PG and BG

\begin{tabular}{|c|c|c|c|c|c|c|}
\hline \multirow{2}{*}{ Property } & \multicolumn{6}{|c|}{ Mixture composition } \\
\hline & BG0.45 & PG0.7 & PG0.8 & PG0.9 & PG-R & PG-L \\
\hline Consistency by Suttard viscosimeter, $\mathrm{mm}$ & 140 & 50 & 50 & 90 & 100 & 55 \\
\hline $\mathrm{pH}$ of fresh paste & 6.8 & 6.3 & 6.3 & 6.3 & 6.4 & 6.5 \\
\hline Dry density, $\mathrm{kg} / \mathrm{m}^{3}$ & 1290 & 1130 & 1050 & 960 & 1060 & 1035 \\
\hline Total porosity, vol. $\%$ & 43.1 & 49.9 & 53.4 & 57.4 & 53.0 & 54.3 \\
\hline Moisture content at $2 \mathrm{~h}, \mathrm{wt} . \%$ & 20.5 & 25.7 & 29.9 & 33.3 & 30.0 & 30.5 \\
\hline Compressive strength $2 \mathrm{~h}, \mathrm{MPa}$ & 6.9 & 5.2 & 4.2 & 3.3 & 1.3 & 3.4 \\
\hline Compressive strength $7 \mathrm{~d}, \mathrm{MPa}$ & 18.9 & 16.5 & 12.0 & 9.6 & 4.6 & 10.1 \\
\hline Initial setting time min & $15: 30$ & $04: 45$ & 04:20 & $04: 30$ & 01:40:00 & 09:30 \\
\hline Final setting time, $\min$ & 00:28:00 & $06: 30$ & $06: 30$ & $07: 45$ & 02:10:00 & $18: 40$ \\
\hline
\end{tabular}

\section{Workability}

The viscosity measurements by viscometer describes workability and its decrease over time which can be associated with the setting time of gypsum binder. After mixing hemihydrate gypsum (PG and BG) with water, the speed of gypsum crystals growing during crystallization was described with the change of paste viscosity (Figure 4). Initial viscosity of all mixtures, except for PG0.7, was $<500 \mathrm{mPa} \cdot \mathrm{s}$. PG0.7 had the lowest possible W/B ratio so that paste can be mixed and tested and it was also indicated by viscometer measurement. The low consistency for PG0.7, PG0.8, PG-L were measured by the Suttard viscometer also indicating the stiffness of paste (50 $\mathrm{mm}$ flow). The initial viscosity for other the mixture compositions were similar at early stage. When the lignosulphonate based plasticizer was used the W/B of composition remained the same but workability slightly increased.

Depending from the W/B ratio the increase of viscosity in time was observed. By the increase of viscosity, the correlation with setting time measured with Vicat apparatus could be seen. The beginning of the viscosity increase for PG0.8 and PG0.9 was almost at the same time and correlates well with initial setting time, which was tinital 4:20 to 4:30 min. The effect of lignosulphonate on gypsum setting time determined with Vicat apparatus indicated retardation of 
initial setting time ( $t_{\text {initial }}$ 9:30 $\mathrm{min}$ ). It is known that the lignosulphonate plasticizers have secondary retardation effect on cement paste setting and similar effect is detected for PG binder (Joel Ogbonna, 2009). The viscosity measurements also show the increase of time when paste is with low viscosity and has correlation with the setting time. Also dynamic viscosity measurements show prolonged working time, the overall consistency determined by Suttard viscosimeter changed slightly (55 mm flow). The BG shows good workability determined by Suttard viscosimeter (145 mm) while the paste viscosity determined by viscometer show similar viscosity to samples made with PG. The setting time of BG was 15:30 min while the paste viscosity in time started to reduced around $5 \mathrm{~min}$ before the setting time determined by Vicat apparatus. The effect of retarder had the highest impact on the setting time and paste viscosity. Also small proportion of retarder was used $(0.5 \%$ from weight of gypsum) the initial setting time increased to tinitial $1 \mathrm{~h} 40 \mathrm{~min}$. The dynamic viscosity measurement was interrupted at 21 min when small increase of paste viscosity was observed.

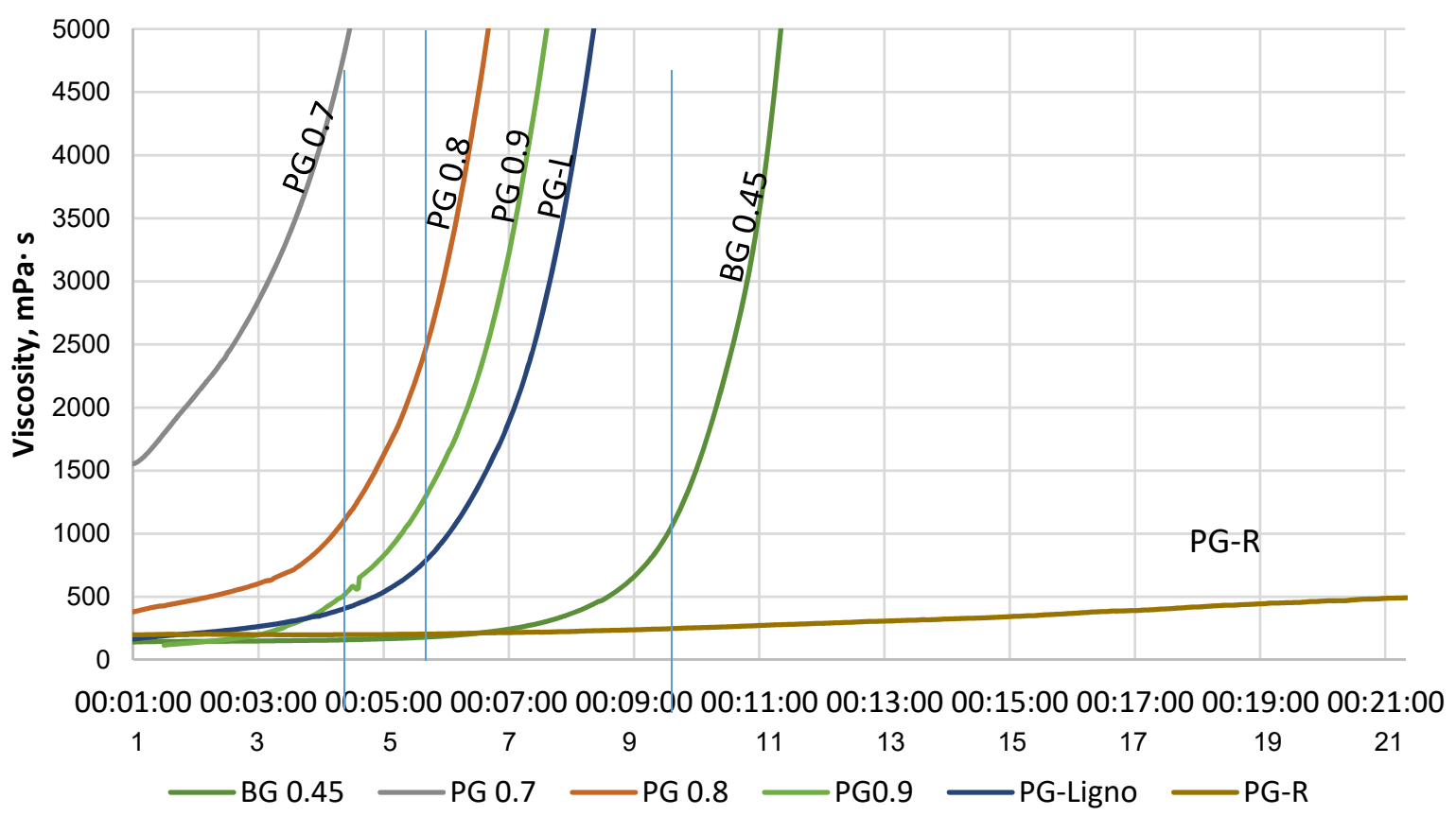

Figure 4. Viscosity kinetics of gypsum paste

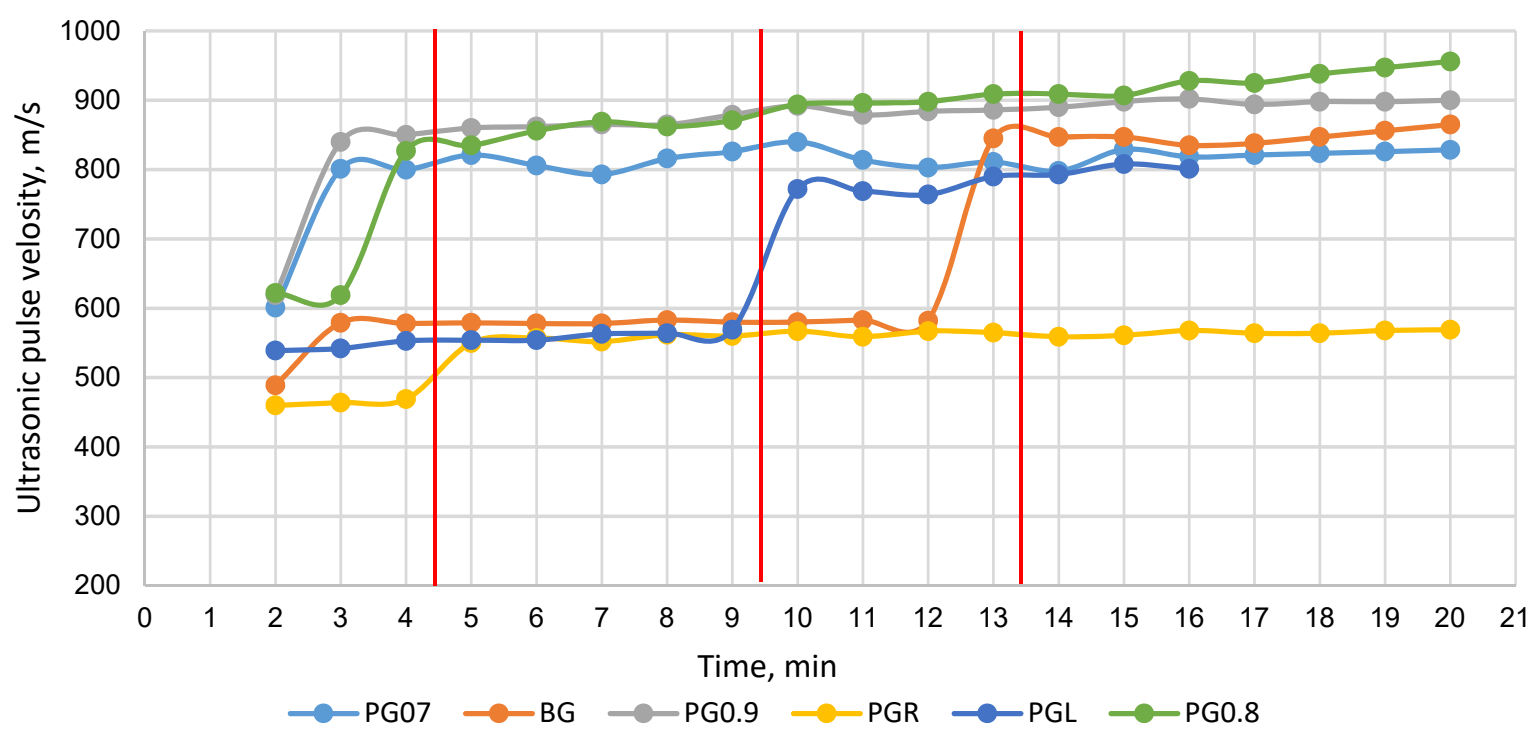

Figure 5. Ultrasonic pulse velocity measurements during gypsum paste setting

The ultrasonic pulse velocity measurements allow to follow the hydration reaction and crystal grow of gypsum binder during setting and these results is in accordance with viscosity measurements and setting time. It can be clearly visible that the setting time can be identified when UWV increase from initial $450-600 \mathrm{~m} / \mathrm{s}$ to $800-850 \mathrm{~m} / \mathrm{s}$ (Figure 5). 
The results can be divided in four groups a) binder based on PG with W/B from 0.7-0.9, where rapid increase of UWV can be identified at 3-4 min; b) PG with plasticizer when rapid increase of the measured speed is identified after $9^{\text {th }}$ minute; c) BG UWV increased after $12^{\text {th }}$ minute and d) for PG with retarder no UWV changes was not observed after $4^{\text {th }}$ minute, when small increase of speed was observed from $450 \mathrm{~m} / \mathrm{s}$ to $550 \mathrm{~m} / \mathrm{s}$.

\section{Conclusions}

The setting time kinetics regarding to viscosity and ultrasonic pulse velocity of fresh phosphogypsum (PG) pastes were studied regarding to W/B ratio and chemical admixtures and results compared to commercial gypsum (BG) binder. The fineness of (PG) binder has influence on W/B ratio and setting time. The W/B ratio for PG binder was 2 times higher comparing to commercial gypsum BG binder. The setting time of PG binder practically was not influenced by W/B ratio while it can be controlled by adding plasticizer and citric acid based retarder in composition. Low W/B in commercial gypsum BG samples results in the highest density $\left(1290 \mathrm{~kg} / \mathrm{m}^{3}\right)$, compared to the density of PG binder samples $\left(960\right.$ to $1130 \mathrm{~kg} / \mathrm{m}^{3}$ ), characterized by $1.55-2$ times higher $\mathrm{W} / \mathrm{B}$ ratio.

The strength of material based on PG was slightly lower comparing to commercial gypsum giving still promising result up to $5 \mathrm{MPa}$ at $2 \mathrm{~h}$ and $16.5 \mathrm{MPa}$ at $7 \mathrm{~d}$ (air dry sample). The addition of retarder reduced the compressive strength of PG binder limiting its potential use. The efficiency of the lignosulphonate plasticizer was observed only on the increase of setting time while $\mathrm{W} / \mathrm{B}$ ratio was not affected. The ultrasonic pulse velocity and dynamic viscosity measurement can be seen as an alternative measurement to detect gypsum setting time which gives good correlation inbetween each other and to results obtained by Vicat apparatus. It was detected that at the beginning of gypsum set the viscosity of gypsum paste rapidly increases above $500 \mathrm{mPa} \cdot \mathrm{s}$ and ultrasonic pulse velocity increases rapidly from $450-600 \mathrm{~m} / \mathrm{s}$ to $800 \mathrm{~m} / \mathrm{s}$. The research of gypsum setting time and its measuring techniques is an important parameter for further development of porous gypsum based materials.

\section{Acknowledgements}

This work has been supported by the European Regional Development Fund within the Activity 1.1.1.2 "Post-doctoral Research Aid" of the Specific Aid Objective 1.1.1 "To increase the research and innovative capacity of scientific institutions of Latvia and the ability to attract external financing, investing in human resources and infrastructure" of the Operational Programme "Development of sustainable and effective lightweight building materials based on secondary resources” (No. 1.1.1.2/VIAA/1/16/050).

\section{References}

Bumanis, G., Zorica, J., Bajare, D., \& Korjakins, A. (2018). Technological properties of phosphogypsum binder obtained from fertilizer production waste. Energy Procedia, 147, 301-308. https://doi.org/10.1016/j.egypro.2018.07.096

Camarini, G., Pinto, M. C. C., Moura, A. G. D., \& Manzo, N. R. (2016). Effect of citric acid on properties of recycled gypsum plaster to building components. Construction and Building Materials, 124, 383-390. https://doi.org/10.1016/j.conbuildmat.2016.07.112

de Moraes Rossetto, J. R., Correia, L. S., Geraldo, R. H., \& Camarini, G. (2015). Gypsum plaster waste recycling: analysis of calcination time. Key Engineering Materials, 668, 312-321. https://doi.org/10.4028/www.scientific.net/KEM.668.312

Dolák, D., \& Dvořák, K. (2016). Impact of plasticizers on technological properties of gypsum. Materials Science Forum, 865, 130134. https://doi.org/10.4028/www.scientific.net/MSF.865.130

Dvořák, D., Gazdič, D., Petranek, V., Hájková, I., \& Magrla, R. (2014). Influence of grinding $\alpha$-gypsum on its final property. Advanced Materials Research, 897, 61-64. https://doi.org/10.4028/www.scientific.net/AMR.897.61

Gaidučis, S. (2009). Mechanical activation and additives influence on extractive hemihydrate phosphogypsum and its products characteristics (Doctoral dissertation, Vilnius Gediminas Technical University, Lithuania). Retrieved from file://C:/Users/33167/Downloads/1775480.pdf

Golež, M., Pogačnik, Ž., \& Mladenović, A. (2018). Laboratory-prepared lime-gypsum mixtures based on the know-how of traditional technology. Journal of Cultural Heritage, 32, 38-43. https://doi.org/10.1016/j.culher.2018.02.011

Joel Ogbonna, F. (2009). The secondary effects of lignosulfonate cement retarder on cement slurry properties. Journal of Engineering and Applied Sciences, 4(9), 1-7. Retrieved from https://pdfs.semanticscholar.org/ccb8/119227de81655ef9c126067ac37467c86bbb.pdf

Kaminskas, A. (2002). Energiją tausojančių statybinių medžiagų technologijos. Vilnius: Technika.

Kaziliunas, A., Leskeviciene, V., Vektaris, B., \& Valancius, Z. (2006). The study of neutralization of the dihydrate phosphogypsum impurities. Ceramics - Silikaty, 50(3), 178-184. http://www.ceramics-silikaty.cz/2006/pdf/2006_03_178.pdf

Lanzón, M. \& García-Ruiz, P. A. (2012). Effect of citric acid on setting inhibition and mechanical properties of gypsum building plasters. Construction and Building Materials, 28(1), 506-511. https://doi.org/10.1016/j.conbuildmat.2011.06.072

Li, G., He, T., Hu, D., Huang, R., \& Shi, C. (2012). Effects of retarders on the fluidity of pastes containing $\beta$-naphthalenesulfonic acid-based superplasticiser. Advances in Cement Research, 24(4), 203-210. https://doi.org/10.1680/adcr.11.00006 
Contreras, J. C. A. (2014). Multi-method approach to study the influence of additives in ternary systems: gypsum, water and impurities (Doctoral dissertation, Clausthal University of Technology, Mexico). Retrieved from https://d-nb.info/1051940737/34

Naceri, A., \& Benia, M. (2006). The effect of fineness of cements at mineral additions on the mechanical response of concrete. Asian Journal of Civil Engineering (Building and Housing), 7(3), 239-248. Retrieved from https://ajce.bhrc.ac.ir/Portals/25/PropertyAgent/2905/Files/6296/239.pdf

Nizevičienè, D., Vaičiukynienè, D., Vaitkevičius, V., \& Rudžionis, Ž. (2016). Effects of waste fluid catalytic cracking on the properties of semi-hydrate phosphogypsum. Journal of Cleaner Production, 137, 150-156. https://doi.org/10.1016/j.jclepro.2016.07.037

Nizevičienè, D., Vaičiukynienè, D., Michalik, B., Bonczyk, M., Vaitkevičius, V., \& Jusas, V. (2018). The treatment of phosphogypsum with zeolite to use it in binding material. Construction and Building Materials, 180, 134-142. https://doi.org/10.1016/j.conbuildmat.2018.05.208

Rashad, A. M. (2017). Phosphogypsum as a construction material. Journal of Cleaner Production, 166, $732-743$. https://doi.org/10.1016/j.jclepro.2017.08.049

Sakthieswaran, N., \& Sophia, M. (2018). Effect of superplasticizers on the properties of latex modified gypsum plaster. Construction and Building Materials, 179, 675-691. https://doi.org/10.1016/j.conbuildmat.2018.05.150

Singh, M. (2003). Effect of phosphatic and fluoride impurities of phosphogypsum on the properties of selenite plaster. Cement and Concrete Research, 33(9), 1363-1369. https://doi.org/10.1016/S0008-8846(03)00068-1 